\title{
Creating a career as a woman composer: Implications for music in higher education
}

\author{
Dawn Bennett, ${ }^{1}$ Sally Macarthur, ${ }^{2}$ Cat Hope, ${ }^{3}$ Talisha Goh ${ }^{4}$ \\ and Sophie Hennekam ${ }^{5}$ \\ ${ }^{1}$ Curtin University, Western Australia, GP0 Box U1987, Perth, WA 6845, Australia \\ ${ }^{2}$ School of Humanities and Communication Arts, Western Sydney University, Locked Bag 1797, Penrith \\ NSW 2751, Australia \\ ${ }^{3}$ Sir Zelman Cowen School of Music, 55 Scenic Boulevard, Monash University, Victoria 3800, Australia \\ ${ }^{4}$ Western Australian Academy of Performing Arts, Edith Cowan University, 2 Bradford St, Mount Lawley \\ WA 6050, Australia \\ ${ }^{5}$ ESC La Rochelle School of Business, 102 rue des Coureilles, 17000 La Rochelle, France
}

d.bennett@curtin.edu.au, s.macarthur@westernsydney.edu.au, cat.hope@monash.edu, talishag@our.ecu.edu.au, hennekamso@esc-larochelle.fr

Recent decades have seen gender and feminist research emerge as major fields of enquiry in musicology and to a far lesser extent, music education. While these fields have increased awareness of the issues confronting women and other marginalised groups, the pedagogical practices and curricular design that might support aspiring women composers are in urgent need of attention. This article reports from an international survey of women composers $(n=225)$, who in western art music continue to experience a masculine bias that has its roots in the past. The findings in the survey were focused on income, work and learning, relationships and networks, and gender. Numerous composers surveyed noted the underrepresentation of music composed by women in their higher education curricula. They also described their unpreparedness for a career in music. The article explores the issue of gender in music composition and makes practical recommendations for a more gender balanced music curriculum in higher education.

\section{Introduction}

While musicology has recently increased awareness of issues confronting women and other marginalised groups, the pedagogical practices and curricular designs that might support aspiring women composers remain in urgent need of attention.

Music composition is typically a specialised area of higher education study and it is central to the preparation of composers. Aspiring women composers comprise between $25 \%$ and $29 \%$ of composition students in Australian higher education institutions (Browning, 2016). According to Parsons and Ravenscroft (2016, p. 4), who sourced data from organisations that represent composers, approximately $20 \%$ of composers across the globe are female. Macarthur et al. (2017) observe similar figures in Australia; however, whilst women composers account for $25 \%$ of the composers represented by the Australian Music Centre, the performance of women's music is significantly less: in 2013, for example, women's music constituted only $11 \%$ of works performed by new music ensembles in Australia (see also Macarthur, 2014). 
Taken together, the low percentage of women composers and the low representation of women's music in performance indicate that music composition remains a male dominated profession. Parsons and Ravenscroft's (2016) review of eight music theory and analysis journals concludes that women's music is also underrepresented in research: from 1994-2013, only $23(1.5 \%)$ of the 1,524 articles reviewed were devoted to music by female composers. Parson and Ravenscroft situate this finding against the unprecedented rise in professional activity and compositional achievement of women over the past century' (p. 4), and contend that women's music is overlooked by the music analytical fraternity.

Looking within higher music education provision, Macarthur's (2007) analysis of six Australian higher education music institutions reveals that women's music is often excluded from classes in musicology and music theory. The male dominance of the curriculum accords with research by Edwards (1997), Green (1997), the British Educational Research Association Music Education Review Group (2004), and O'Toole (n.d., accessed 2007).

A further gendered concern within higher music education is that of competition. Long et al's (2014) analysis of masterclass experiences reveals that female students are more likely than males to attend masterclasses as observers rather than performers, and significantly more likely to perceive masterclass performance experiences as unfriendly or intimidating. Long et al. (p. 190) conclude that learning and engagement behaviours 'are subliminally driven by stereotypical male orientations, particularly in definitions of artistic excellence and cultural power'.

Concerned about diversity, Peters (2016) brought together students and faculty at the University of Wisconsin to identify and address unintended exclusionary practices. Participants discovered that, until the 1970s, only $1 \%$ of music in the university's concert programs had been composed by women; in 2013 , this had reached only $6 \%$. Participants also learned that women had composed only $15 \%$ of works programmed in the institution's contemporary (new) music concerts. Peters (p. 26) concluded that the programming of our major ensembles represents and reinforces long-held traditions tied to gender'. The under-representation of women and people of diverse cultural backgrounds led the faculty to ask how many of their students would be able to visualise themselves within the curriculum.

These observations are supported by research that highlights the continued masculine bias in Western art music. Redhead (2015) situates the bias as a patriarchal category with its roots in the past, and McClary (1991), Cusick (1999) and Macarthur (2010) agree that the seemingly neutral concept of the music itself is fundamentally gendered. Furthermore, Born and Devine (2015, p. 151) suggest a link between the epistemology of sound and its gender: that 'sound reproduction and manipulation - including today's digital music technologies - emerged from a historical conjunction governed by a hegemonic rationalist masculinity locked in a dualistic relation with its subordinate feminine Other'.

Commentators agree that gender inequality impacts both aspiring and practicing women composers. Of particular relevance here, scholars from the United Kingdom, Australia and the United States (see Fowler, 2006; Macarthur, 2010, 2014; Henderson, 2015; Browning, 2016; Pitman et al., 2016) all support the claim that higher education has a critical role to play in negating inequality. 
Table 1. Sample demographics

\begin{tabular}{|c|c|c|c|c|c|c|}
\hline \multirow{2}{*}{\multicolumn{2}{|c|}{ Age }} & \multicolumn{3}{|c|}{$\begin{array}{c}\text { Experience by age; hours per week, } \\
\text { by age }\end{array}$} & \multirow{2}{*}{\multicolumn{2}{|c|}{ Location }} \\
\hline & & \multicolumn{2}{|c|}{$\begin{array}{l}\text { Composition } \\
\text { experience }\end{array}$} & \multirow{2}{*}{$\begin{array}{l}\text { Composition } \\
\text { hours per } \\
\text { week } \\
\% \text { of sample }\end{array}$} & & \\
\hline Age & $\%$ & Years & $\%$ of sample & & Location & Count \\
\hline$<21$ & 3.5 & $0-10$ & 21 & 33 & North America & 69 \\
\hline $21-30$ & 31.4 & $11-20$ & 26 & 43 & & \\
\hline $31-40$ & 28.3 & $21-30$ & 26 & 14 & Australasia & 61 \\
\hline $41-50$ & 14.6 & $31-40$ & 14 & 7 & & \\
\hline $51-60$ & 12.8 & $41-50$ & 7 & 1 & Europe & 48 \\
\hline $61-70$ & 5.8 & $51-60$ & 6 & 0 & & \\
\hline $71-90$ & 2.2 & $61+$ & 1 & 1 & $\begin{array}{l}\text { Africa/Asia/South } \\
\text { America }\end{array}$ & 6 \\
\hline
\end{tabular}

\section{Method}

\section{Participants}

Respondents were recruited via email, university and industry websites, and social media. Initial contacts were asked to forward the invitation to their networks. As this is an unknown population, no response rate is reported. Respondents had practiced as composers for a mean of 20 years and their average age was 38.04 with a range from 18 to 88 years. Respondents reported becoming composers at a mean of 18 years, most probably aligning with the commencement of higher education studies. Composition work was self-defined and included music composition together with the preparation of scores, work with performers, and the administration of the composer's practice.

The composers worked in multiple genres including contemporary classical, electronic, orchestral, jazz, and film music. $71 \%$ of respondents held paid roles for 30 hours or more per week. Their weekly work in composition was reported as less than ten hours (35\% of respondents) to 60 or more hours $(1.3 \%)$. A demographic breakdown is included at Table 1 and the dominant genres reported by composers are shown at Table 2.

\section{Instrument}

Participants were invited to complete a detailed survey, split into three parts and distributed at two-monthly intervals. The survey instrument explored education and training, career trajectories, gender, how work is obtained or created, and collaboration. Items were developed through an in-depth literature review and the input of the research team members, who were educators, composers and creative workforce researchers. 
Table 2. Compositional genres or foci reported by participants

\begin{tabular}{lcc}
\hline \hline Dominant genre or focus & Number of participants & Percentage (\%) \\
\hline Contemporary classical & 121 & 55 \\
Electroacoustic & 13 & 5.9 \\
Experimental or new music & 36 & 16.4 \\
Jazz & 4 & 1.8 \\
Multiple genres, not categorised & 9 & 4.1 \\
New age & 2 & 0.9 \\
Performance art & 1 & 0.5 \\
Popular / contemporary & 7 & 3.2 \\
Sound art & 5 & 2.3 \\
Theatre and film & 15 & 6.8 \\
World music & 5 & 2.3 \\
Not defined & 1 & 0.5 \\
Lyrical & 1 & 0.5 \\
\hline \hline
\end{tabular}

The instrument was trialled and refined twice before the final version was created. It consisted mostly open questions and incorporated duplicate items for the purposes of triangulation, validity and reliability. The survey was distributed in English; however, because one of the team members was Dutch and the survey attracted interest from The Netherlands, a Dutch version was created using back-and-forth translation. The survey was hosted online using SurveyMonkey.

\section{Procedures}

Ethical approvals were obtained before commencement and respondents received an information sheet and an assurance of anonymity. Closed questions were analysed using SPSS and qualitative responses were analysed manually using content analysis (Stemler, 2001). Frequency counting identified recurrent patterns in the data (Wilkinson, 2011), taking into account synonyms and possible multiple meanings (Weber, 1990). To reduce error and bias, two researchers independently coded the data (Mays \& Pope, 2000). Coding was compared and refined until agreement was reached; inter-rater reliability met the cutoff point of .80 .

The results and discussion are organised in three emergent themes: work and learning, relationships and networks, and gender. The themes are highlighted with direct quotations from the respondents, and we begin by setting the context with an overview of the composers' work.

\section{Results}

Context

Most respondents reported concerns about their financial sustainability. They reported unpaid commissions, rehearsals, mentorship, musical direction, and administrative work 
for music ensembles and festivals. Although the composers had generated a composition income for an average of 13 years, composition revenue was inconsistent: for example, 45 respondents had not generated a composition income during the previous financial year. Most income came from sources other than composition, with teaching the most common of these. Whilst the majority of composers aspired to eventually make a living from their composition practice, they did not expect this to eventuate. Some composers, settling for a portfolio of roles, found that this model of work afforded them artistic freedom and greater financial security.

\section{Becoming established}

Several established composers noted the progression of their thinking from idealistic to realistic. Although some composers reported that their careers were better than they had imagined, most of them emphasised that their training had not equipped them to search for the opportunities that had underpinned their success.

My career path has exceeded all my expectations. My compositional 'training' was entirely academic. No-one pointed me any direction as to how to become a composer in the 'real' world! (R43, 50 years of experience, contemporary classical)

Twenty per cent of respondents noted that they had graduated with no strategies for attracting work. Grant funding, for example, emerged as an important source of income. Highlighting the need for effective grant-writing, composers underlined that these skills had not been developed during their higher education studies. Respondents also emphasised that during their training they had developed little understanding of the composer's practice.

I'm definitely in the thick of it, and when I undertook my training I didn't really have a clue what I was doing, what I was entering into. I am fighting to stay in this industry. (R56, 26 years of practice, theatre and film; piano)

Respondents had not anticipated how long it would take to become established and they had been unprepared for the longer-term, unstable income that the majority of respondents endured. The composers were often compelled to take unrelated work. Unaware that this is normal practice for musicians (Hennekam \& Bennett, 2017), they tended to position this work as a sign of failure.

I have a full-time day job to pay rent and bills . . . I imagined that I would create music for a range of different scenarios (ensembles, films, radio broadcast, theatre, interactive artworks, maybe even an orchestra etc.) and be paid for it, enough that I could support myself from my creative practice. (R59, 8 years of practice, theatre and film)

Remarking on the extent to which higher education prepares composers for their careers, few respondents were initially confident about how to promote themselves and their practice. As a result, many composers had adopted an ad-hoc approach to visibility, reputation-building, access and networking. Although they recognised the importance 
of an online presence, few composers understood how to create or manage this aspect of their practice.

\section{Work and learning}

The composers were highly qualified, with 94\% reporting an undergraduate degree and $79 \%$ reporting a post-graduate degree. Using a Likert scale where 1 was least effective and 10 was very effective, the composers rated the effectiveness of their undergraduate education as 5.6 out of 10 . Six recommendations emerged from the open questions that followed. The discussion section returns to each of these themes.

1. Develop students' skills in multiple genres: 'anything that gets you composing and earning money' (R42, contemporary classical composer);

2. Encourage students to experiment and take risks: 'more personal involvement for students: experimental music, improvisation, writing their own stuff' (R18, jazz composer);

3. Present 'Music by women ... and discuss the history of exclusion of women or of the impact of gender on a musical career' (R30, jazz composer);

4. Include more 'diverse repertoire including music by women and those outside the western canon' (R13, theatre and film composer);

5. Prepare students 'for the realities of the music industry' by including business skills, new technologies and the basics of music law (R2, new age composer); and

6. Provide opportunities for students to 'have access to musicians (students and visiting professional ensembles) and simulated professional situations' (R4, contemporary classical composer).

To overcome initial deficits, composers turned to books, blogs, journals, and social media. They listened to music from multiple genres and created informal peer learning opportunities such as jam sessions, improvisation, festivals, masterclasses and workshops. The composers also operated as mentors and as peer reviewers of musical scores and funding proposals.

Development programs involving workshopping as well as performance of works ... create a supportive environment allowing for questions to performers, for the testing of alternative compositional ideas, and for feedback about what is effective [and] practical. (R37, 11 years of experience, contemporary classical)

A pervasive feature of the composers' accounts was the need to develop new skills and knowledge. This learning was often relayed as 'filling the gaps' left by formal studies. A negative aspect of many industry events was that they can have a competitive rather than a collaborative focus, and that others can be unintentionally gendered; these did not meet their professional learning needs. The established composers also emphasised the need for a learning mindset, adding that reputational capital is insufficient to sustain a career in composition. 
It's taken a very long time (or feels like it) to build a profile in the industry. To build a solid body of work, which people can refer to, and to build a network of clients who continue to commission me. I still feel like it could fall apart any second, and there is little to no job security. (R57, 13 years of experience, world music: traditional Celtic)

Composers were generally positive about their informal learning activities, but they bemoaned the dearth of female role models and mentors. Similarly, numerous composers recalled the under-representation of women's music in their degree classes and ensemble programmes, including those in new music.

Role models are critical! I had no personal female role model, nor an awareness of any (other than Alice Parker and Natalie Sleeth) when I was studying music in the late1970s. I believe this had a direct impact on my decision at the time to forgo further composition. Instead, the time I spent writing music dropped to virtually zero for 30 years. (R66, 20 years of experience, contemporary classical)

My mentors at [university] were mainly the postgraduate students rather than the lecturers (and they were far more supportive). I don't have a mentor now and I think this is a big issue. My career has completely stagnated/ground to a halt over the past couple of years and I don't know how to get it going again. (R59, eight years of experience, theatre and film; orchestral pop; modern exotica)

Actually, in all my education, I was only ever taught by one female (and she was unpleasant to say the least), so there were certainly no role models in terms of teachers/lecturers. (R54, four years of experience, contemporary instrumental and electronic)

Respondents were asked to comment on the gender of their composition teachers. Of the 82 responses to this question, 54\% reported that they had had no female composition teachers. One respondent preferred male teachers over her female teacher; otherwise, female teachers were described as more supportive and more caring.

I think women care more about all the aspects of artistic formation of their students. The women teachers I had were more concerned, and more encouraging. (R168, 20 years of practice, experimental or new music)

One woman composition teacher was noted as included other women composers in her classes. Others were seen as more concerned about students' well-roundedness and more concerned about the details of compositions in progress.

I would not claim a binary divide, but personally, I try to let all my students develop their OWN skills and never attempt to move them into any particular style. I know many male teachers who do this. (R87, c. 50 years of practice, contemporary classical)

Respondents reported that music composed by women was rarely, if ever, included during their higher education studies. They mentioned concert programs, class discussions, library collections, texts and set or studied works. 
The composers held an average of 2.6 different paid roles within and beyond music. In some cases, these roles were synergetic.

It is just one life, and I do everything I do at the highest level possible. Everything feeds into everything else and nothing can be neglected. I welcome income from all strands and consider it a support for everything that I do. (R22, 33 years of experience, contemporary classical)

Composers stressed the need to respond to changes in career aspiration and personal priorities. These often aligned with moments such as parenthood, which prompted a desire for more stable income, less travel and increased flexibility.

Becoming a parent led me to travel less while my daughter was small, so higher profile, international collaborations were more challenging. I also stopped applying for international residencies, as children are seldom welcome in these environments. (R30, 30 years of experience, jazz with popular music influence)

Of interest, strategies employed to alleviate emotional, financial or career stress were often temporary. One group of participants explained that financial constraints had initially led them to defer their composition careers, returning only once their personal or financial circumstances had changed.

At age 30, I gave up and went for a non-arts career and at age 45 I started coming back, and that's accelerating so that I am now reducing days in my 'day job'. (R49, 20 years of experience, popular and contemporary music)

A core feature of sustainable work was the support of family and peers, with moral support mentioned most frequently. This was followed with practical support that enabled the composers to have increased time for composition. Lack of support from a significant other had negative consequences.

\section{Relationships and networks}

Composition was described as a solitary activity, and relationships with performers were important and valued. This was consistent across musical genres, and the greatest influences on sustaining relationships were personality, approaches to work, context, and ensemble size. Asked about how composer-performer relationships are first established, only $14.7 \%$ of the composers made most of the initial approaches. A further $37.5 \%$ reported that composer- and performer-initiated approaches were roughly equal, and $37.5 \%$ of composers relied mostly on approaches from performers. As might be expected, composers were more likely to be approached by performers once they had established their careers and reputation.

Yes, I'd like to think people approach me more now than say 12 years ago when I was despondently trying to 'make it'. I've worked damned hard for this to be the 
case though, and will continue to do so for the indefinite future. (R34, 19 years of experience, contemporary classical)

As their reputations grew, $48 \%$ of composers were more confident in contacting performers. The remaining $42 \%$, however, continued to wait for performers to call. This indicates that whilst the importance of networks and relationships is understood by composers, some do not utilise them to grow their businesses. As seen below, confidence appears to be at the core of this.

The groups I work with seem to like what I do and be prepared to do more. I haven't yet really dared cold call high-level professionals. (R29, three years of experience, contemporary classical/neo-romantic)

Almost half the respondents composed for their own ensembles, with new works created once or twice each year. Highlighting once more the importance of social capital for musicians, commissions for new works came from a variety of sources including friends, colleagues, producers, performers and peers, and also from organisations and ensembles known to the composers.

Most of what has worked the best for me has come through already established connections. (R22, 33 years of experience, contemporary classical)

Performer relationships were described as symbiotic and fluid, and some composers wrote of continuous interaction and reciprocity. The challenge of weak relationships was voiced by the following composer.

I find it almost impossible to compose when there is limited communication with musicians. This is because I really tailor my music to each player's strengths and unique playing style. I'm currently writing a piece for an ensemble where the members in the ensemble haven't really engaged with me ... I have not written a note! (R4, ten years of experience, contemporary classical and electroacoustic)

Relationships and networks were considered to be particularly important in early career at which time, ironically, most composers felt least able to create and sustain them. Both face-to-face and online networks were vital. Overall, the development of networks and relationships required pro-active behaviours, persistence, self-promotion, the careful management of relationships, and excellent networking skills. These emerged as core skills rather than soft skills, as described below.

You need to market yourself - no one will do it for you! (R33, 29 years of experience, electroacoustic and electronic)

Some get ahead by unending self-promotion, some get ahead by plain hard work, and some use their connections and networks to further their careers. I'd guess most find some kind of balance between the three. (R21, 15 years of experience, contemporary classical) 
Despite emphasising the importance of the online environment, only $61 \%$ of the composers had their own website and less used Facebook, Twitter or YouTube on a regular basis. Only $32 \%$ made regular use of LinkedIn, alumni networks, listservs, discussion groups, or Instagram.

\section{The impacts of gender}

Almost half the participants (46\%) reported that gender impacted the likelihood of their work being performed. There were both positive and negative effects of gender in that some ensembles promote music composed by women because it is less common, whilst others dismiss the music of women as 'less serious'. Many composers were aware that gender bias is systemic, and rather than personalise it they sought strategies to overcome it. One composer described her strategy to target women conductors and ensembles with female members.

It seems to me that if it is a group made up primarily of women, they will be more likely to program my music. I believe women conductors are more likely to program my music than male conductors, although I do not believe they are aware that this bias exists. (R21, 15 years of experience, contemporary classical)

The composers noted that some aspects of music are particularly gendered. These included electronic music and jazz, and the stereotype that women are less proficient with technology.

I was infuriated when a well-known theatre director dropped by the dress rehearsal for my feminist chamber opera (with electronics) and asked if a particular male sound designer had created the electronic score. I'm the composer! I made it! . . . there was an assumption that I couldn't have handled it and could only have composed the vocal aspects of the piece. (R30, 30 years of experience, jazz with popular music influence)

One of the respondents described a palpable discrimination, performed as a set of attitudes and actions.

Outright discrimination - both behaviourally and verbally. I've been told (multiple times over the past 20 years) I wouldn't know where to plug anything in and I should just give up/leave the studio/gig . . . Gigs aren't offered to you, even though you're looking for them. You're not invited to 'join the band'. It all sounds really clichéd, but it's all happened multiple times. (R59, eight years of experience, theatre and film, orchestral pop, modern exotica)

Women described various strategies to counteract gendered behaviour: for example, exposing gender imbalances, promoting positive discrimination, incorporating the works of women composers when teaching and lecturing, becoming role models, and creating exposure for women's work through what one composer called 'aggressive programming'. 
In general, the issue will only be resolved when women work together and protest as loudly and as often as possible. (R10, unknown years of practice, New Age) I do think it's about everyday visibility, flooding people's feeds with women in action, making instances of gender exclusion visible and gradually. (R37, 11 years of practice, contemporary classical)

... when you program a concert, and play these works, the audience are blown away by them - and want more. (R2, 38 years of practice, New Age)

Some women mentioned that creating electronic music allowed them to take full control of the compositional process, making it more likely that they could hide their identity (and perhaps their gender). Despite research showing women in electronic music find it difficult to get their music programmed into labels, festivals and concert opportunities (Female Pressure, 2015), several respondents considered the electronic music genre to be egalitarian and welcoming to women.

. . . there is an active community of female electronic and electro-acoustic musicians . . . My they have always been very generous about sharing knowledge and information, and gender hasn't really been an issue: the focus has always been on the art. (R24, 14 years of practice, contemporary classical)

Sound art and installation art provide opportunities for solo work, and many visual and new media art galleries and venues are managed by women and progressive men. This takes women musicians and composers out of the entrenched structures of classical music, still very dominated by old misogynist, imperialist, racist, colonialist beliefs and practices. (R21, 15 years of practice, contemporary classical)

Virtual reality is also a good place to explore, as identity is a very fluid concept there. All of these new technologies and genres are examining culture, indigeneity, sexuality, gender roles, etc. It is where the progressive thought is occurring. (R21, 15 years of practice, contemporary classical)

\section{Discussion}

Cultural theorist Terry Threadgold (1996, p. 281) argues that to be competent in any discipline

. . . is to learn to embody, to perform, and to enact on a daily basis . . . as everyday pedagogy, not only the academic genres that constitute the theories and practices of the discipline, but also the genres of social relations and embodied subjectivity that construct the discipline as 'a body' of knowledge, and that determine its intersections and social relations with other disciplines, and other institutions, other 'bodies' of knowledge.

To be competent, then, is to proficiently perform the genres of the discipline and to speak, write and reproduce its dominant discourses and practices. It follows that if those dominant discourses and practices are 'patriarchal to the core' (Threadgold 1996, p. 281), learners will tend to adopt versions of the male 'other'. 
Threadgold asks at what point a female subject might erase dominant voices and learn to speak from the position of 'others', including women, while remaining credible in the academy or discipline. This leads to the question of whether it is possible to reconstruct a discipline from within. If it is, the poststructuralist feminisms used for this deconstruction might impact the academy and/or the social world. An example of this is seen in Gould's (2005) analysis of the female band leader - an occupation marked by gender and race segregation in which women and people of colour are positioned as outsiders. Gould employs the concept of the nomad as conceived by Deleuze and Guattari and taken up by Braidotti (1994) to show how the feminist, nomadic subject - the female university band director - can transgress disciplinary boundaries and conventions by dint of having a minority status. In so doing, Gould argues, she takes up alternative subjectivities in which she can assume political agency.

Although Threadgold (1996) and Gould (2005) make convincing cases for adopting a critical pedagogy, Hess (2017) warns that it can produce undesired effects such as polarising western art music against popular and non-western music. Hess's rationale is that while a critical pedagogy challenges canonic dominance by including a range of music and diminishing the emphasis on notation, it also perpetuates the dominance of western art music by positioning other music as subordinate. In Hess's (2017) view, a critical pedagogy might also account for individuals' positionalities in terms of how the effects of race, gender, class, and so on, re-inscribe the very hegemonic values and relations that a critical pedagogy attempts to erase.

The counter-argument to Hess is that by not introducing critical thinking and social justice, male dominance will prevail. Adding weight to this argument is Vaugeois' (2007) point that specialised music training can make invisible the political nature of music. As such, the authors contend that music in higher education must develop students' broad and critical understandings of music's societal and global relevance. Within this broad, contextual understanding, music in higher education needs to address the rights, responsibilities and realities of musicians' practice, including the gendered nature of work (see also Bennett, 2008).

A traditional curriculum also perpetuates the linear model of training that prepares students for mythological careers as performers or creators rather than the protean career that is likely to be the reality. Although there has been much curricular reform within higher education over recent years, in this study the reports of inadequate career preparation came from respondents whose higher education experiences were many years in the past and by those whose careers were just beginning. To manage their composition practice, graduates require skills and practices in business and new technologies together with awareness of their legal rights and responsibilities. They should be conversant in multiple genres (gendered or not), used to taking creative risks, familiar with female role models and composers, exposed to a diverse repertoire, engaged with relevant networks and social media, and familiar with how to approach and work with performers. Aspiring composers need to learn when and how much to charge, and how to create paid commissions. Moreover, the prepared composer will 'have learned how to learn' in order to meet their professional learning needs as graduates, including through informal and online learning experiences (McClary, 2016). 
Technology merits special attention as it aligns with 'male' attributes such as control, mastery, expertise and skill (Armstrong, 2011). In music, gendered alignment is constructed at an early age. Shibazaki and Marshall (2013), for example, note that among primary school students, girls are less confident, more self-critical and less keen than boys to create music using technology. Similarly, Green (1997) reports that female secondary school students are more successful with notated, classical music, whilst boys excel in improvisation and composition. Green (1997) suggests that, in combination, technology and popular music have the potential to be particularly gendered; this challenge is as real in higher education as it is in the primary and secondary school.

\section{Conclusion}

\section{Limitations and future research directions}

The findings of this study cannot be generalised internationally or across all higher education institutions and genres. There may also be differences between composerperformer interactions with professional or amateur, funded and unfunded ensembles. A limitation of the study is that it involved only women; other researchers might investigate challenges experienced by men and by composers with diverse sexual orientations. Future research might seek to build on this study with a sample that enables the nuanced analysis of select themes. Researchers might also extend the study with in-depth research in a specific locale, ideally with a longitudinal study that enables single cases to be viewed across the career lifespan. These aspects are important and merit further attention.

\section{Recommendations for higher education}

This article argues that despite the attention of scholars since Green's (1997) study, the curriculum and practices of music in higher education are still dominated by male representation. The following recommendations are made in the hope that they might contribute to meaningful change. Common to these recommendations is the need for aspiring musicians to develop the metacognitive capacities needed to negotiate challenging careers (Gaunt \& Westerlund, 2013; Bennett, 2016). Trede and McEwen (2016, p. 7) describe this as becoming deliberate professionals who embrace transparent, lateral decisions and practices 'informed by deliberative thinking and deliberate action'. At the core of such deliberative development is a mindful and inclusive curriculum that challenges students to conceptualise multiple and inclusive musical worlds.

Welch and colleagues (2008, p. 214) suggest that music's multiple discourses relating to gender and genre 'act as independent factors in influencing musicians' self-perceptions and attitudes towards music learning and teaching in higher education'. Threadgold (1996) is optimistic that the processes of deconstructing and making explicit the practices of a discipline can work to influence and empower the disenfranchised, and Peters' (2016) student-faculty research at the University of Wisconsin is just such an example. Peter's faculty and students deconstructed and made explicit gendered instrument selection (see also Marshall \& Shibazaki, 2011), jazz participation (see also North, Colley \& Hargreaves, 2003), the role of female founders, and gender imbalance within school and university 
curricula. Peter's faculty and students recognised the 'power of unifying energy' (p. 28) to create change. Although they acknowledged the negative connotations of positive discrimination, participants introduced 'specialised programming' including concerts of works by women. They also reviewed music history texts and curriculum, shared their findings via publicly displayed posters, ensured that speakers and presenters included female musicians and musicians of colour, and established a student-faculty committee to addresses diversity. As co-researchers, many students and faculty changed their teaching and performing practices and became advocates for equality. Whilst the challenges and possibilities will vary, strategies such as those applied in Wisconsin are achievable anywhere.

Returning to music technology, Born and Devine (2015, p. 150) highlight the sexual stereotyping of technology and expose a dominance of the male canon in both the traditional music degree and the music technology degree, with the latter degree also privileging the male subject and alienating the female through 'an observable process of gendered exclusion - occupationally, spatially, and practically'. These discriminatory discourses 'effect the exclusion of women composers from the music-historiographic canon' (Born \& Devine, 2015, p. 149). They also perpetuate a digital creative field that is 'dominated by male practitioners, male lecturers and male authors' (O'Keeffe, 2017). Higher education institutions are recommended to lessen this dominance by ensuring that women teach and engage in the music technology curriculum, and that women are present as strong role models.

Building on the work of Threadgold (1996), Macarthur (2010) describes how the music and attitudes of the composer-educator combine to create a version of the composer that reproduces the music itself and the associated attitudes of the training. Because of this, the model of training is self-perpetuating: 'the dominant music produces the composer; and the composer produces the dominant music, endlessly' (p. 43). As the attitudes and actions of a teaching practice have a powerful impact on the formation of the future composer, a strong recommendation is that the music of women and other marginalised groups be used as exemplars in higher education music curricula, including in performance programming. Institutions might also invite women composers to lecture or as residents. This would grant composers valuable access to studio space and performance opportunities as well as exposing students to female role models and the nature of composition practice.

University environments present a valuable opportunity for composers to create initial professional networks, both within the student cohort and through lecturers and visiting artists. Community internships and placements offer valuable opportunities for student musicians to review their ideological assumptions and become aware of opportunities for work and funding. In addition to the more obvious settings, female students might work with primary school children for whom dominant discourses have not yet been 'learned' (Charles, 2004), thus avoiding 'the stereotype of composition as a male preserve' (Hanley, 1998, p. 68). These strategies are likely to contribute to student composers' self-identity and self-efficacy (see Burland \& Davidson, 2002).

Assessment criteria must be broadened to recognise peer-learning, risk, creativity and improvisation. Broader assessment practices enable students to experiment with technology and with different types of music, trying multiple approaches as they develop their personal 
style. Creating regular opportunities to work with performers has implications for the performance curriculum and might lead to assessment practices that encourage performers to learn repertoire outside the canon, particularly if combined with the work of student composers and artists-in-residence. It also heralds opportunities for graduate ensembles to access studio and performance spaces in return for engaging with new music. Similarly, all student composers need to learn how and why to maximise their media presence. Some students might adopt the role of 'experts' who guide the learning of peers and educators, creating opportunities for the development of teaching skills. It is likely that student-led learning will promote greater diversity, particularly if these opportunities are inter-disciplinary.

Taken together, music in higher education has multiple opportunities to support the development of women composers, including their preparedness to negotiate the many obstacles they will face when they enter the workforce and confront normalised sexist attitudes. Only if they develop their critical understanding will students will be equipped to challenge inequality as deliberate professionals. Acknowledging that change will take time, the most important recommendation is for all composition students and music educators to be made aware of gendered behaviours and under-representation, and to be empowered to create change from within their own practice.

\section{References}

ARMSTRONG, V. (2011) Technology and the Gendering of Music Education. Aldershot: Ashgate.

BECKER, G. (1964) Human Capital. New York: Columbia University Press.

BENNETT, D. (2008) A gendered study of the working patterns of classical musicians: Implications for practice. International Journal of Music Education, 26, 89-100.

BENNETT, D. (2016) Developing employability in higher education music. Arts and Humanities in Higher Education, 15, 386-395.

BORN, G., \& DEVINE, K. (2015) Music technology, gender, and class: Digitization, educational and social change in Britain. Twentieth-Century Music, 12, 135-172.

BOURDIEU, P. (1989) Social space and symbolic power. Sociological Theory, 7, 12-25.

BRAIDOTTI, R. (1994) Nomadic Subjects: Embodiment and Sexual Difference in Contemporary Feminist Theory. New York: Columbia University Press.

BRITISH EDUCATIONAL RESEARCH ASSOCIATION (BERA), Music Education Review Group (2004). Mapping Music Education Research in the UK. Psychology of Music, 32, 239-90.

BROWNING, J. (2016) Equal Arts: Discussion Paper. Melbourne: Victorian Women's Trust.

BURLAND, K. \& DAVIDSON, J. W. (2002) Training the talented. Music Education Research, 4(1), 121-140.

CHARLES, B. (2004) Boys' and girls' constructions of gender through musical composition in the primary school. British Journal of Music Education, 12(3), 265-277.

CUSICK, S. G. (1999) Performing/composing/woman: Francesca Caccini meets Judith Butler. In S. Macarthur \& C. Poynton (eds.), Musics and Feminisms (pp. 87-98). Sydney: Australian Music Centre.

EDWARDS, R. (1997) Changing places? Flexibility, lifelong learning, and a learning society. London: Routledge.

FEMALE PRESSURE Female: Pressure - Facts 2015. https://femalepressure.wordpress.com/facts-survey2015/ FOWLER, J. (2006) Where are the Women? Music Forum, 13, 24-25.

GAUNT, H. \& WESTERLUND, H. (2013) Collaborative Learning in Higher Music Education. Farnham: Ashgate Publishing. 
GOULD, E. (2005) Nomadic turns: Epistemology, experience, and women university band directors. Philosophy of Music Education Review, 13, 147-164.

GREEN, L. (1997) Music, Gender, Education. Cambridge: Cambridge University Press.

HANLEY, B. (1998) Gender in secondary music education in British Columbia. British Journal of Music Education, 15, 51-69.

HENDERSON, M. (2013) Music bosses remain deaf to distortion that gender discrimination creates on stage. Sydney Morning Herald, October 11. http://www.smh.com.au/comment/ music-bosses-remain-deafto-distortion-that-gender-discrimination-creates-on-stage-20131010-2vb09.html

HENNEKAM, S. \& BENNETT, D. (2017) Creative industries work across multiple contexts: Common themes and challenges. Personnel Review, 46(1), 68-85.

HESS, J. (2017) Critiquing the Critical: The Casualties and Paradoxes of Critical Pedagogy in Music Education. Philosophy of Music Education Review, 25, 171-191.

LONG, M., CREECH, A., GAUNT, H. \& HALLAM, S. (2014) Conservatoire students' experiences and perceptions of instrument-specific master classes. Music Education Research, 16, 176-192.

MACARTHUR, S. (2007) Gender and the tertiary music curriculum in Australia. Music in Australian Tertiary Institutions: Issues for the 21st Century, 1-38.

MACARTHUR, S. (2010) Towards a Twenty-First-Century Feminist Politics of Music. Farnham, England \& Burlington, USA: Ashgate.

MACARTHUR, S. (2014) The woman composer, new music and neoliberalism. Musicology Australia, 36, $36-52$.

MARSHALL, N. \& SHIBAZAKI, K. (2011) Two studies of musical style sensitivity with children in early years. Music Education Research, 13, 227-240.

MAYS, N. \& POPE, C. (2000) Qualitative research in health care: Assessing quality in qualitative research. British Medical Journal, 320, 50-52.

MACARTHUR, S., BENNETT, D., GOH, T., HENNEKAM, S. \& HOPE, C. (2017). The rise and fall, and the rise (again) of feminist research in music: 'What goes around comes around'. Musicology Australia, 39, 73-95.

MCCLARY, S. (1991) Feminine Endings: Music, Gender, and Sexuality. Minneapolis \& Oxford: University of Minnesota Press.

McCLARY, S. (2016) From the universal and timeless to the here and now: Rethinking music studies. In S. Macarthur, J. Lochhead, \& J. Shaw (eds.), Music's Immanent Future: The Deleuzian Turn in Music Studies (pp. 25-35). London: Routledge.

NORTH, A. C., COLLEY, A. M. \& HARGREAVES, D. J. (2003) Adolescents' perceptions of the music of male and female composers. Psychology of Music, 31, 139-154.

O'KEEFFE, L. (2017) Women in sound: addressing the music industry's gender gap. The Conversation. http://theconversation.com/women-in-sound-addressing-the-music-industrys-gender-gap-85132

O'TOOLE, P. (N.D.). Gender Research in Music Education (G.R.I.M.E). http://post.queensu.ca/ grime/ proposal.html (accessed March 17, 2007)

PARSONS, L. \& RAVENSCROFT, B. (2016) Analytical Essays on Music by Women Composers: Concert Music, 1960-2000. Oxford: Oxford University Press.

PETERS, G. (2016) Do students see themselves in the music curriculum? A project to encourage inclusion. Music Educators Journal, 102, 22-29.

PITMAN, T., ROBERTS, L., BENNETT, D., \& RICHARDSON, S. (2017) An Australian study of graduate outcomes for disadvantaged students. Journal of Further and Higher Education. Published online July 1. doi:10.1080/0309877X.2017.1349895

REDHEAD, L. (2015) New music as patriarchal category. In C. Haworth \& L. Colton (ed.), Gender, Age and Musical Creativity (pp. 171-184). Farnham, England \& Burlington, VT: Ashgate. 
SHIBAZAKI, K. \& MARSHALL, N. A. (2013) Gender differences in computer-and instrumental-based musical composition. Educational Research, 55, 347-360.

STEMLER, S. (2001) An overview of content analysis. Practical Assessment, Research \& Evaluation, 7, $1-5$.

THREADGOLD, T. (1996). Everyday life in the academy: Postmodernist feminisms, generic seductions, rewriting and being heard. In C. Luke (ed.) Feminisms and pedagogies of everyday life, (pp. 280-314). Albany: State University of New York Press.

TREDE, F., \& MCEWEN, C. (2016) Carving out the territory for educating the deliberate professional. In F. Trede \& C. McEwen (ed.), Educating the Deliberate Professional (pp. 15-28). Springer International Publishing.

VAUGEOIS, L. (2007) Social justice and music education: Claiming the space of music education as a site of postcolonial contestation. Action, Criticism, and Theory for Music Education, 6, 163-200.

WEBER, R. P. (1990) Basic Content Analysis. Newbury Park, CA: Sage.

WELCH, G., PAPAGEORGI, I., HADDON, L., CREECH, A., MORTON, F., DE BEZENAC, C. . . \& HIMONIDES, E. (2008). Musical genre and gender as factors in higher education learning in music. Research Papers in Education, 23, 203-217.

WILKINSON, R. (2011) Changing interactional behaviour: Using conversation analysis in intervention programmes for aphasic conversation. In C. Antaki (ed.) Applied Conversation Analysis: Changing Institutional Practices (pp. 32-53), Basingstoke: Palgrave Macmillan.

Dawn Bennett is John Curtin Distinguished Professor of Higher Education with Curtin University and Director of the Creative Workforce Initiative. Her research is focused on developing employability within higher education learning and teaching, including identity development and graduate work.

Sally Macarthur is an Associate Professor whose books include Towards a Twenty-FirstCentury Politics of Music (Ashgate, 2010), Feminist Aesthetics in Music (Greenwood, 2002) and, co-edited with Judy Lochhead and Jennifer Shaw, Music's Immanent Future: The Deleuzian Turn in Music Studies (Routledge, 2016).

Professor Cat Hope is a composer, sound artist, musician and artistic director. She is the co-author of 'Digital Arts - An introduction to New Media' (Bloomsbury, 2014) and director of the Decibel new music ensemble. Her research includes digital music archives, graphic notations and very low frequency sound.

Talisha Goh is a Musicology PhD candidate at the Western Australian Academy of Performing Arts, with a dissertation focus on contemporary Australian women composers. Research interests include Australian music history, gender studies and multidisciplinary studies.

Sophie Hennekam is an associate professor interested in identity transitions, diversity management and the creative workforce. She has published in journals such as Human Relations and Human Resource Management Journal. 